\title{
Laughing Matters: ELLs' Comprehension and Perceptions of Humor
}

\section{Talip Gönülal1}

Type/Tür:
Research/Araştırma
Received/Geliş Tarihi: August
27/27 Ağustos 2018
Accepted/Kabul Tarihi:
December 8/ 8 Aralık 2018
Page numbers/Sayfa No: 453-468
Corresponding
Author/Illetişimden Sorumlu
Yazar:
talip.gonulal@erzincan.edu.tr

\section{$\checkmark$ iThenticate}

This paper was checked for plagiarism using iThenticate during the preview process and before publication. / Bu çalışma ön inceleme sürecinde ve yayımlanmadan önce iThenticate yazılımı ile taranmıştır.

\section{Copyright $(\odot) 2018$ by}

Cumhuriyet University, Faculty of Education. All rights reserved.
Humor is probably one of the few features applicable to virtually all people in the world, but the perception and appreciation of humor can be circumstantial and culture-dependent. Although the potential role of humor in language classrooms has been the topic of research over the last years, limited research has been conducted on cross-cultural variability in humor perception and appreciation. The current study, seeking to address this gap, was conducted with a multicultural group of English language learners (ELLs). One hundred and six ELLs consisting of three main groups (i.e., Turkish, Asian and European) took part in this study. After completing a language background questionnaire, participants rated 6 humorous scenarios and then completed a 25-item humor perception questionnaire. Further, participants answered three open-ended questions at the end of the questionnaire. The results indicated that learners generally assigned more positive scores to universal jokes when compared to linguistic and cultural jokes. As for the perception of humor use in English classrooms, Asian group held slightly less positive attitudes towards the use of humor whereas Turkish group was the one most interested in the employment of humor. In addition, the results indicated that humor was linked to several benefits such as lowering affective barriers to English language learning, increasing ELLs' attentiveness in the classroom and improving teacher-student rapport.

Keywords: Humor, cultural humor, linguistic humor, universal humor, English language learners

\section{Suggested APA Citation/Önerilen APA Atıf Biçimi:}

Gönülal, T. (2018). Laughing matters: ELLs' comprehension and perceptions of humor. Cumhuriyet International Journal of Education, 7(4), 453-468. http:// dx.doi.org/10.30703/cije.455199

\footnotetext{
1 Dr. Öğretim Üyesi, Erzincan Binali Yıldırım Üniversite, Eğitim Fakültesi, İngiliz Dili Eğitimi, Erzincan/Türkiye Assistant Professor, Erzincan Binali Yildirim University, Faculty of Education, English Language Teaching, Erzincan/Turkey e-mail: talip.gonulal@erzincan.edu.tr ORCID ID: https:/ / orcid.org/0000-0001-6441-4278
} 


\title{
Gülmek Önemlidir: İngilizce Öğrenen Öğrencilerin Mizah Anlayışı ve Algısı
}

\begin{abstract}
Öz
Mizah muhtemelen tüm insanlar için geçerli olan birkaç unsurdan biridir, ancak mizahın algılanışı ve takdir edilmesi bazı koşullara ve hatta kültüre bağlı olabilir. Mizahın yabancı dil öğrenme üzerindeki potansiyel etkisi son dönemde araştırılmaya başlansa da, mizah algısındaki kültürlerarası değişkenlik çok az ele alınmıştır. Bu yüzden, farklı kültürlerden gelen bir öğrenci grubuyla bir çalışma yapılmıştır. Toplamda üç genel gruptan (Türk, Asyalı, ve Avrupalı) oluşan 106 öğrenci bu çalışmaya katılmıştır. Katılımcılar önce 6 adet farklı türde mizah unsuru içeren senaryoları puanlayıp, sonra 25 soruluk mizah algı anketini doldurmuşlardır. Son olarak da 3 adet açık uçlu soruyu cevaplamışlardır. Sonuçlar, öğrencilerin dilsel ve kültürel mizaha kıyasla evrensel mizah unsuru içeren senaryolara daha pozitif yaklaştı̆̆ını göstermiştir. Yabancı dil derslerinde mizah kullanımı konusunda ise Asyalı öğrenciler biraz olumsuz tutum takınırken Türk öğrenciler mizaha en açık grup olmuştur. Buna ek olarak, sonuçlar, mizahın İngilizce dil öğrenimine karşı oluşan duyuşsal engelleri azaltmak, öğrencilerin derse olan katılımını artırmak ve öğretmenöğrenci arasındaki iletişimi güçlendirmek gibi çeşitli faydalarının olduğunu göstermiştir.
\end{abstract}

Anahtar Kelimeler: Mizah, kültürel mizah, dilsel mizah, evrensel mizah, İngilizce öğrenen öğrenciler

\section{Introduction}

Humor is an inevitable part of human discourse. Humorous interaction, to a greater or lesser extent, also occurs in classrooms (Wulf, 2010). Indeed, as the focus of language learning and teaching has shifted from teacher-oriented teaching to a more student-oriented one, a "new interest in non-serious language" has gained popularity (Bell, 2017, p. 445). Over the years, a great number of scholars in general education (e.g., Berk, 1996, 2000; Berk \& Nanda, 1998; Garner, 2006; Neuliep, 1991; Schmitz, 2002; Torok, McMorris \& Lin, 2004; Wanzer, Frymier \& Irwin, 2010, and others) have investigated the use of this 'hardwired' characteristic of human beings in classrooms. Before reviewing the findings of humor research, it is necessary to start with the concept of humor itself. Humor has been used as an "umbrella term" (Attardo, Wagner \& Urios-Aparisi, 2013, p. 2). There are, thus, several different definitions of humor but the element that remains constant across definitions is that humor includes incongruous yet entertaining elements (Martin, 2007). For instance, Gervais and Wilson (2005) defined humor as "non-serious social incongruity" (p. 399). Similarly, Banas, Dunbar, Rodriguez and Liu (2011) described humor as the employment of verbal and nonverbal communication that creates joy and amusement. As for the classroom humor, it can be broadly defined as any spoken, written, visual or performed action that the students or the teacher find funny or amusing in class, even if it is not inherently funny (Gonulal, 2018).

\section{Humor within General Education}

There has been increasing interest in humor research in the recent years. Several studies in social sciences, especially in education and psychology fields, have examined the use of humor from different perspectives. For instance, humor researchers have investigated: (a) the theories and classification of humor (Schmitz, 2002), (b) the use of humor by teachers and students (Berk, 1996, 2000; Berk \& Nanda, 
1998; Neuliep, 1991; Torok et al., 2004), (c) the types of humor and their effects on learning (Wanzer et al., 2010), and (d) when and where to use humor in an educational setting (Garner, 2006).

Humor has been linked to a number of pedagogical roles beyond providing amusement (e.g., Berk, 2000; Wanzer et al., 2010). To illustrate, Neuliep (1991), who investigated the effects of humor on classroom teaching, reported that "teachers use humor as a way of putting students at ease, as an attention-getter, as a way of showing that the teacher is human, as a way to keep the class less formal, and to make learning more fun" (p. 354). In a longitudinal questionnaire-based study, Berk (2000) looked at the physiological and psychological effects of humor in testing. Berk reported that both undergraduate and graduate students felt that humor was quite functional for decreasing their test anxiety and assisting them in performing better on tests. In a more recent study, Wanzer et al. (2010) studied how instructional humor could facilitate learning. Based on the incongruity theory, in which 'surprise and unexpectedness' is considered as the primary source of humor, they developed the instructional humor processing theory. Wanzer et al. argued that learners first have to comprehend and then decode the incongruous elements in humorous materials embedded in instruction. The recognition of the incongruity will eventually increase learners' attention. This increased attention can boost the learnability of the input and can, thus, contribute to learning. Overall, humor studies collectively indicate that classroom humor enhances the learning experience in several ways.

\section{Humor and Language Learning}

The fast developing interest in humor is also reflected in a small yet growing body of second language (L2) humor research because humor is mediated mostly through language. That is, learning a language also includes learning how to recognize and produce humor in the L2. Research has provided evidence that humor can be used as an effective factor in the language learning process. From psychological aspects, several studies (e.g., Askildson, 2005; Forman, 2011; Petraki \& Nguyen, 2016; Wagner \& Urios-Aparisi, 2011) have shown that teacher-led language play might lessen the language anxiety and in turn, create positive impact on English language learners' (ELLs) engagement in the language learning process. Likewise, Pomerantz and Bell (2011) argued that humor can serve as a 'safe house' for language learning. In looking at the cognitive functions of humor, language play in L2 education has been reported to increase the depth of processing lexical items and to make learning more memorable, which implies that humor or language play can be of great help in language acquisition. In light of this, Bell (2009) explored the nature of humorous communication in second language classrooms in detail. Bell's study drew on several data sources ranging from classroom observations and interviews to audio- and video-analyses of ELLs' interaction. Bell reported that employing, examining and analyzing humorous materials in various manners can lead to L2 learners' sociolinguistic development, along with linguistic development.

In a similar vein, Forman (2011) conducted a study on humorous language play with post-beginner ELLs at a Thai university. Forman investigated how language play contributed to ELLs' development of affective, sociocultural, and linguistic aspects. The study comprised of interviews with nine English teacher and nineteen hours of classroom observation. The results showed that despite ELLs' 
limited L2 production skills, their willingness to participate was high. Given that, Forman argued that teacher-led language play might lessen foreign language anxiety and in turn create positive effects on students' engagement in the learning process. In another study conducted with Vietnamese ELLs, Petraki and Nguyen (2016) investigated the university instructors' humor practices in English language courses and their perceptions regarding the functions of classroom humor. The results indicated that the instructors tended to use both prepared and spontaneous humor in various forms (e.g., funny comments, stories, examples, jokes) at least seven times during a typical class period mostly to draw students' attention and to create a more relaxed learning atmosphere.

Despite the pedagogical potentials of humor, a possible issue in using humor in a language classroom relates to whether humor will be appreciated or not. That is, what is intended as humorous may not elicit a smile or laugh due to several reasons such as ineffective delivery or a lack of contextual understanding on the part of the listener. In fact, when L2 learners are considered, it is highly likely that most of the humorous situations that induce native speakers to laugh may not have the same effects on L2 learners. Taking this into consideration, Deneire (1995) highlighted that language teachers can employ humor in language classrooms only when the learners possess the crucial "cultural and linguistic resources" needed to comprehend humor and language play (p. 286). On the other hand, Schmitz (2002) disagreed with this statement and argued that humor can and should be used with language learners even at early stages. Schmitz proposed a category of jokes that can be utilized with ELLs in English language classrooms. According to Schmitz, jokes that involve universal elements of humor (e.g., exaggeration, hyperbole, irony etc.) are the easiest to understand for a language learner and can thus be used with beginning level learners, whereas culture-based jokes require higher language proficiency as well as a thorough knowledge of the target culture. When it comes to linguistic humor, it calls for high language proficiency to be successfully processed, so it may not be appropriate to use such type of humor with lower level language learners. Mirroring Schmitz's suggestion of humor typology, Bell (2005) found that there is a direct correlation between learners' language proficiency levels and the comprehension and appreciation of language play. This implies that as proficiency level increases, the likelihood of understanding and producing native-like humorous utterances increases correspondingly

In addition to language proficiency, culture may play an important role in comprehending and appreciating humor because most salient distinctions among cultures lie in the structure and formation of humor and in the ways people perceive humor or humorous speech (Banas et al., 2011). Regarding that, Yue, Jiang, Lu and Hiranandani (2016) noted humor "seems to manifest differently in Western and Eastern cultures" and added that these differences can be "attributed to the Western individualistic versus Eastern collectivistic" cultural orientations (p. 1). For instance, compared to American students, Chinese students may have relatively negative attitudes towards classroom humor probably because of the hierarchical structure of the teacher-learner relationship in Chinese culture (Chen \& Martin, 2007; Jiang, Yue \& Lu, 2011; Liao, 2001; Zhang, 2005). On the other hand, Turkish students, for example, 
may find classroom humor quite effective considering the Turkish people's tendency to use the elements of humor in their daily lives (Gonulal, 2018).

Overall, although the potential role of humor in language classrooms has been the topic of research over the last years, scant attention has been given to crosscultural variability in the appreciation of humor. Further, there is also a scarcity of research examining English language learners' comprehension of humor. Further research is definitely needed in these areas. Although humor has a lot to offer English language learners, they may respond differently to humor due to their potentially different levels of comprehension and appreciation of humor. The purpose of this study, therefore, is to explore whether there are cultural differences in English language learners' comprehension of humor, and whether there is any variability in their appreciation of classroom humor. Therefore, the following research questions guided this study:

1. To what extent do ELLs show variability in their comprehension of humor?

2. How do ELLs perceive the use of humor in English classroom?

\section{Method}

In this study, a mixed-methods design was employed to examine the intricate nature of humor and to provide a complete picture of the phenomena. More specifically, a convergent parallel mixed-methods research design (Cresswell \& Plano-Clark, 2011) was adapted. Both quantitative data (i.e., humorous scenarios and questionnaires) and qualitative data (i.e., answers to open-ended questions) were gathered and then separately analyzed but the interpretation of the findings of quantitative and qualitative data was conjointly done.

\section{Participants}

The data were initially gathered from 110 English language learners. However, four participants did not provide any information about their language background and were, therefore, excluded from the subsequent analyses. This reduced the sample size to 106 participants. All participants were university students in the US and were coming from a variety of cultural backgrounds (e.g., Turkish, Chinese, Korean, German, Spanish, and so forth). Participants were mostly graduate students $(60 \%)$ and were majoring in various fields such as education (14\%), business and economics $(11 \%)$, engineering $(10 \%)$, TESOL $(10 \%)$, psychology $(6 \%)$, food science $(5 \%)$, communication $(5 \%)$, forestry $(4 \%)$, and mathematics $(4 \%)$.

Since there was not enough sample representing each cultural group, participants were divided into different groups based either on their self-rated English proficiency levels, humor beliefs scores, geographical location or a combination of the three. As can be seen in Table 1, this categorization resulted in three main groups: Turkish $(n=43)$, Asian $(n=40)$, and European $(n=23)$. Participants ranged in age from 22 to 39 years old. The mean age at which participants started learning English was 11, and the mean length of learning English was 12 years. Participants met the minimum language proficiency requirement (i.e., TOEFL IBT score above 79) set by graduate schools. 
Table 1

Participant demographic information

\begin{tabular}{|c|c|c|}
\hline Language Groups & $\mathrm{N}$ & $\%$ \\
\hline Turkish & 43 & 39.1 \\
\hline Asian & 40 & 36.4 \\
\hline Chinese & 23 & 20.9 \\
\hline Korean & 12 & 10.9 \\
\hline Bahasa & 1 & .9 \\
\hline Hindi & 1 & .9 \\
\hline Indonesian & 1 & .9 \\
\hline Taiwanese & 1 & .9 \\
\hline Urdu & 1 & .9 \\
\hline European & 23 & 20.9 \\
\hline German & 8 & 7.3 \\
\hline Spanish & 8 & 7.3 \\
\hline Russian & 3 & 2.7 \\
\hline Czech & 1 & .9 \\
\hline Polish & 1 & .9 \\
\hline Portuguese & 1 & .9 \\
\hline Serbian & 1 & .9 \\
\hline Not reported & 4 & 3.9 \\
\hline
\end{tabular}

Table 2

Self-rated English language proficiency for four skills

\begin{tabular}{lccccc}
\hline Groups & $\mathrm{N}$ & $\begin{array}{c}\text { Reading } \\
\mathrm{M}(\mathrm{SD})\end{array}$ & $\begin{array}{c}\text { Writing } \\
\mathrm{M}(\mathrm{SD})\end{array}$ & $\begin{array}{c}\text { Listening } \\
\mathrm{M}(\mathrm{SD})\end{array}$ & $\begin{array}{c}\text { Speaking } \\
\mathrm{M}(\mathrm{SD})\end{array}$ \\
\hline Turkish & 43 & $4.40(0.69)$ & $4.28(0.85)$ & $4.21(0.86)$ & $4.04(0.92)$ \\
Asian & 40 & $4.35(0.95)$ & $4.03(0.97)$ & $3.78(0.94)$ & $3.63(0.98)$ \\
European & 23 & $4.70(0.47)$ & $4.57(0.51)$ & $4.43(0.59)$ & $4.07(0.77)$ \\
Total & 106 & $4.43(0.77)$ & $4.24(0.86)$ & $4.09(0.87)$ & $3.87(0.89)$ \\
\hline
\end{tabular}

Note. 1 = beginner level, 5 = advanced level.

As can be seen in Table 2, participants' self-rated proficiency level was quite high (upper-intermediate to advanced) in that all four skills averaged above 4 out of 6 , with reading being the highest and speaking being the lowest.

\section{Instruments}

A comprehensive 'humor in English language learning' survey created to elicit ELLs' responses to statements regarding the use humor in English classrooms and to measure ELLs' comprehension of humor. The survey consists of four parts: (a) a background information section, (b) a humorous scenarios section, (c) a 6-point Likert-scale humor perception questionnaire (i.e., the HELL questionnaire), and (d) an open-ended questions section.

The background information section included six questions pertinent to ELLs' language learning background. The humorous scenarios section included six humorous scenarios based on a variety of sources (e.g., Internet, humor books and studies). Following Schmitz's (2002) categories, these scenarios were grouped into 
three main types: universal jokes, linguistic jokes and cultural jokes. Participants were asked to rate each scenario on a scale from 'not funny' (1) to 'extremely funny' (5) and then to briefly explain why they think it is funny or not.

The HELL questionnaire, which was designed by Gonulal (2018), involved 25 humor-related items that address how ELLs perceive the use of classroom humor. The HELL questionnaire went through a robust development and validation process (see Gonulal, 2018 for further details). The reliability of the questionnaire was quite high (i.e., Cronbach's alpha = .88; Plonsky \& Derrick, 2016) and was thus considered suitable for the data collection in the present study. In the open-ended questions section, participants were asked to share their beliefs and experiences regarding the use of humor in English classrooms (i.e., Tell us about the funniest English class you ever had. What made it so funny? What did you like most about this funny English class? What did you like least about this funny English class?).

\section{Procedure, Data Collection and Analysis}

An online version of the survey created via Qualtrics survey tool was used to collect data. At the beginning of the survey, participants were provided with an operational definition of classroom humor. They were also asked to provide a rationale for their ratings on the humorous scenarios and were requested to take the humor perception questionnaire and to answer the open-ended questions section based on their current and previous English language learning experiences. The survey took approximately 20 minutes.

In order to analyze the data, both quantitative and qualitative methods were employed. Basic descriptive statistics (i.e., mean and standard deviation) were calculated on all parts of the survey. In addition, 95\% confidence intervals were reported when necessary as a measure of showing the probability of the significance of the mean differences. Before conducting any statistical tests, a comprehensive missing value analysis (MVA) was run. The MVA results showed that approximately $12 \%$ of the data were missing, which was larger than the suggested cut-off level of $5 \%$ in the missing data analytic literature (Tabachnick \& Fidell, 2013). Given that, a multiple imputation method was performed on the variables to remedy the issue of missing data (for further details see Gonulal, forthcoming and McKnight, McKnight, Sidani \& Figueredo, 2007).

Following the results from the exploratory factor analysis in Gonulal (2018), the humor perception questionnaire was analyzed under four factors (for further information on factor analysis, see Loewen \& Gonulal, 2015; Plonsky \& Gonulal, 2015). As presented in Table 3, the first factor that includes items related to ELLs' preference of teachers with sense of humor was labelled desired teacher characteristics. The second factor, labelled low affective barriers, contains items that focus on how using humor can be effective in lowering affective barriers to learning English such as stress and anxiety. The third factor was labelled increased attentiveness and attention span because items in this factor collectively point to the attention-gathering power of humor. The last factor, labelled increased learner confidence, relates to the effects of humor on making ELLs more courageous to attend the classroom teaching. Finally, a content analysis was performed on the qualitative data 
Table 3

Factors of the humor perception questionnaire

Factor 1: Desired Teacher Characteristics

8. I want the English instructor to have a sense of humor.

11. I find English instructors who use jokes more effective in teaching English.

19. I prefer taking English courses with an English instructor who uses humor in the classroom

Factor 2: Low Affective Filter

2. When the English instructor uses humor in the classroom, I feel my stress level decreases.

4. When the English instructor uses funny examples in the classroom, I feel anxious.

17. I feel more stressed when the English instructor uses funny examples.

18. Having an English instructor who uses humor reduces my stress about learning English.

20. I feel more comfortable when the English instructor uses humor in the classroom.

Factor 3: Increased Attentiveness and Attention Span

1. I am more attentive in class when the English instructor uses humor.

6. I am more likely to pay attention to the topics when the English instructor uses funny examples in the classroom.

10. When the English instructor uses funny examples, it makes me more interested in learning English.

13. An English instructor who has a sense of humor encourages me to learn English.

22. I do not miss an English class when I find the class funny.

Factor 4: Increased Learner Confidence

21. I do not feel anxious when I laugh in the classroom.

23. When the English instructor uses humor in the classroom, I am not afraid to ask questions.

24. I am not afraid of making mistakes in the classroom where humor is used frequently.

\section{Quantitative Results}

\section{Results}

ELLs rated several humorous scenarios on a scale of 1 (not funny) to 5 (extremely funny). As can be seen in Table 4, the results of the humorous scenarios indicate that overall the international students assigned higher scores to universal humor $(M=$ $3.15, S D=.87,95 \% \mathrm{CI}[2.92,3.38])$ and linguistic humor $(M=2.88, S D=.99,95 \% \mathrm{CI}$ $[2.62,2.52])$ than culture-oriented humor $(M=2.28, S D=.94,95 \% \mathrm{CI}[2.06,2.52])$. This difference was statistically significant when examining the non-overlapping confidence intervals $([2.92,3.38]$ and $[2.62,3.14]$ vs $[2.06,2.52]$, respectively). Although there were no significant between-group differences, Asian group assigned more positive scores to linguistic humor compared to Turkish and European groups whose highest scores were on universal humor.

Table 4

Descriptive statistics for humor comprehension

\begin{tabular}{llccc}
\hline Groups & $N$ & $\begin{array}{c}\text { Universal Humor } \\
M(S D)\end{array}$ & $\begin{array}{c}\text { Linguistic Humor } \\
M(S D)\end{array}$ & $\begin{array}{c}\text { Cultural Humor } \\
M(S D)\end{array}$ \\
\hline Turkish & 43 & $3.19(0.85)$ & $2.91(1.05)$ & $2.31(0.96)$ \\
Asian & 40 & $3.03(1.12)$ & $3.05(0.96)$ & $2.20(1.08)$ \\
European & 23 & $3.25(0.63)$ & $2.69(0.92)$ & $2.37(0.67)$ \\
Total & 106 & $3.15(0.87)$ & $2.88(0.99)$ & $2.28(0.94)$ \\
\hline
\end{tabular}

Note. 1 = not funny, 5 = extremely funny. 
Following the factors on the humor perception questionnaire, average scores for each language groups were calculated. Table 5 presents the results of this language-by-language comparison. Overall, all three groups had quite positive beliefs regarding the employment of humor in English classrooms. More specifically, Factor 2 received the highest score $(M=4.86, S D=.72,95 \% \mathrm{CI}[4.68,5.04])$ followed by Factor $4(M=4.57, S D=.77,95 \% C I[4.38,4.77])$ and Factor $1(M=4.56, S D=.94$, $95 \%$ CI $[4.33,4.80])$ whereas Factor 3 received the lowest score $(M=4.46, S D=.79$, $95 \%$ CI $[4.25,4.67])$.

Table 5

Descriptive statistics for humor perception factors

\begin{tabular}{lcccc}
\hline Groups & $\begin{array}{c}\text { Factor 1: } \\
\text { Desired teacher } \\
\text { characteristics } \\
\mathrm{M}(\mathrm{SD})\end{array}$ & $\begin{array}{c}\text { Factor 2: } \\
\text { Low affective } \\
\text { filter } \\
\mathrm{M}(\mathrm{SD})\end{array}$ & $\begin{array}{c}\text { Factor 3: } \\
\text { Increased } \\
\text { attention and } \\
\text { attentiveness } \\
\mathrm{M}(\mathrm{SD})\end{array}$ & $\begin{array}{c}\text { Factor 4: } \\
\text { Increased } \\
\text { confidence } \\
\mathrm{M}(\mathrm{SD})\end{array}$ \\
\hline Turkish & $4.91(0.77)$ & $5.05(0.68)$ & $4.73(0.63)$ & $4.84(0.69)$ \\
Asian & $4.15(0.91)$ & $4.64(0.73)$ & $3.97(0.77)$ & $4.10(0.59)$ \\
European & $4.45(1.37)$ & $4.69(0.81)$ & $4.56(0.92)$ & $4.70(0.95)$ \\
Total & $4.56(0.94)$ & $4.86(0.72)$ & $4.46(0.79)$ & $4.57(0.77)$ \\
\hline
\end{tabular}

Note. 1 = strongly disagree, 6 = strongly agree.

An examination of the group differences shows that Asian group's scores on all four factors were lower than those of Turkish and European groups. Among the three groups, Turkish group had the most positive attitudes towards the employment of humor. Further, there were statistically significant mean differences between Turkish and Asian groups regarding Factor 1, Factor 3 and Factor 4 given the non-overlapping confidence intervals $(95 \% \mathrm{CIs}=[4.62,5.19]$ vs $[3.74,4.55] ;[4.50$, $4.98]$ vs $[3.58,4.37] ;[4.59,5.10]$ vs $[3.82,4.38]$, respectively). However, there were no significant differences between the Turkish and European groups regarding their perceptions of humor.

\section{Qualitative Results}

Sixty-eight ELLs made comments on the open-ended questions at the end of the survey. The content analysis on the open-ended questions data revealed several themes and patterns that were mostly consistent with the factors in the humor perception questionnaire. The first theme concerns learners' preference of humororiented English teachers in their English classrooms probably because it makes teachers more approachable. For example, in Example 1, the learner stated that the employment of humor by English teacher can improve teacher immediacy.

Example 1. My teacher's personal experiences and stories are the funniest times in my class. It makes me feel close to the teacher. (a Spanish learner)

The second theme had to do with the psychological effects of classroom humor. As can be seen in Examples 2 and 3, the learners expressed that the way their English 
teachers used humor helped create a comfortable, relaxed and stress-free classroom atmosphere which was more conducive to learning.

Example 2. The teacher was acting in a funny and exaggerated way when teaching. Happy mode was always on. Happy atmosphere! No pressure! ( $a$ Chinese learner)

Example 3. The teacher made use of a funny game with an invisible ball to help us learn each other's names. It was fun to start a lesson that way. It helped us communicate and get to know each other in a short amount of time without making us nervous. (a Korean learner)

In a similar vein, several learners noted that when the classroom environment was more relaxed they tended to take more part in classroom activities. This can be seen in Examples 4 and 5.

Example 4. In my listening \& speaking and grammar courses at [removed]. His name is [removed]. He was telling a lot of jokes and making funny faces when teaching. He is the best! We did not feel bored at all and we were always participating to the class because he made us more relaxed and awake. And I took another course with him. (a Turkish learner)

Example 5. My teacher was using funny games and stories. It was the funniest class...everyone was making many mistakes but it triggered our willingness to ask questions without hesitation. After each game, we were looking forward to being in the same class the following week! (an Indonesian learner)

Another theme that emerged from the learner comments relates to the potential power of using humor in English classrooms on ELLs' linguistic development. As illustrated in Examples 6 and 7, the learners viewed the use of humor as an effective way of improving their vocabulary knowledge and, to some extent, pragmatic knowledge probably because humorous materials often contain authentic language use.

Example 6. We were watching funny movies in the class and laughing together because of the comedian's actions and jokes, as well...In this class, I learned English in a funny way...I learned slang words and more about the sense of humor of foreign people out of my country. (a Turkish learner)

Example 7. The teacher was generally using humor from daily life...I felt I was learning new phrases, new usage of everyday language, and professional terms, and grammar. (an Indian learner)

The last theme is slightly different from the factors on the humor perception questionnaire in that the drawbacks of using classroom humor were raised by a number of students. Indeed, if not used effectively, classroom humor might have some unfavorable effects on learning. Examples 8 through 10 are illustrative of this.

Example 8. It made me tired, because there were a lot of jokes going on, and I could not understand some of them, but I tried to understand as much as possible. Therefore, at the end of the class I was feeling so tired. (a Turkish learner)

Example 9. Our teacher was a very funny person, but some students were trying to take advantage of her in the exams and quizzes. Perhaps, it would have been better if she had been a little bit serious when it comes to the exams and quizzes. (a Russian learner) 
Example 10. Sometimes, I was confused about that because I didn't understand what the funny part was. Sometimes it was hard to understand the jokes. ( $a$ Chinese learner)

Overall, the four themes emerging from the qualitative data overlap mostly with the factors produced from the quantitative data. The only difference lies in the fact that in the qualitative data, the ELLs also touched upon the negative sides of the employment of humor in the classroom

\section{Discussion}

This small-scale study attempted to investigate how a multicultural group of ELLs comprehended a set of humorous scenarios and perceived the employment of humor in English classrooms, and to what extent they showed any variability in their comprehension and perceptions of humor. The quantitative and qualitative data gathered from a variety of ELLs coming from different cultures revealed several important findings. To begin with, ELLs approached universal humor and linguistic humor more positively than culture-based humor. This inclination among ELLs mirrors the findings of the previous humor studies (e.g., Schmitz, 2002) which reported that universal humor is the easiest for ELLs to comprehend, closely followed by linguistic humor whereas cultural humor is the least favored one. One possible explanation for this discrepancy is that universal humor often includes incongruous elements which require counter-intuitive ways of thinking and reasoning. The conflict created through incongruous element in humorous materials are typically easy to detect, if not easy to comprehend, and are not strictly related to language proficiency or cultural knowledge. On the other hand, linguistic humor requires some level of proficiency on the part of the learner because humorous elements in linguistic humor are pertinent to linguistic features. When it comes to cultural humor, learners need to have not only the necessary linguistic knowledge but also cultural knowledge to decode humorous element and then to find the association between culture and the humorous concept.

Additionally, ELLs reported what they thought and how they felt regarding the four factors (i.e., desired teacher characteristics, lower affective barriers, increased attentiveness and attention span, and increased learner confidence) on the humor perception questionnaire. Overall, ELLs considered humor to be one of the desirable characteristics of English teachers. The first theme which emerged from the qualitative data were also in line with this finding in that ELLs found humor-oriented teachers more close and reachable. Indeed, previous humor research within general education indicated that teachers who employ an appropriate dose of humor are often more popular among students (Wanzer et al., 2010). Although ELLs collectively believed that sense of humor should be one of the necessary teacher traits, there seemed to be some cross-cultural variability in the degree of importance. That is, Turkish students' preference over humor-oriented English teachers was significantly higher than that of Asian students. One possible explanation for this difference might be the stratified structure of the teacher-student rapport in Asian, particularly Chinese, culture (Chen \& Martin, 2007; Yue et al., 2016; Zhang, 2005). Contrary to this, Turkish students may find humorous English teachers quite approachable when they attempt to use non-serious language in serious and often teacher-fronted language teaching environments. Indeed, humor can serve as a useful pedagogical tool at such 
an interim stage (i.e., from a teacher-oriented teaching to a more student-oriented teaching).

The remaining three factors, which were also largely reflected in learner comments, concerned mostly psychological effects of classroom humor on learners. In line with previous humor research (e.g., Forman, 2011; Petraki \& Nguyen, 2016), humor was reported to have the potential to lower psychological barriers to language learning such as stress, tension and anxiety. This tension-relieving potential of humor, in turn, can create a safe house for language learning (Pomerantz \& Bell, 2011) which is likely to lead to increased learner confidence in using English and to higher learner participation in classroom discussions (Illés \& Akcan, 2017). Another important point that was revealed only in the qualitative data relates to the role of humor or humorous materials on linguistic development. As Bell (2009) highlighted, implementing appropriate level and amount of humor in English classrooms can help ELLs develop not only linguistic but also sociolinguistic development because authentic language is often used in humorous materials.

Despite the numerous pedagogical potentials of classroom humor, a few concerns were raised in the qualitative data. For example, several learners pointed out that the excessive employment of humor in classroom can do more harm than good. Demotivating some learners (Wanzer, 2002), depreciating the seriousness of instruction (Zhang, 2005) and even poor classroom management (Schmitz, 2002) feature notably as the drawbacks of excessive and improper use of humor. Although there are no established guidelines regarding the optimal amount of humor, Gonulal (2018) suggested that the ideal dosage of humor in a typical 50-minute English course should be 3 or 4 times and the humorous materials should be non-offensive, contentspecific and appropriate for learners' age and level of proficiency.

There are several limitations to this study. First, although the sample size is not large enough, it can serve as a fair representation of the population of ELLs in the world. Second, due to the low participation rate for certain language groups, using self-rate language proficiency levels, humor perception scores, geographical location or a combination of these as criteria in the formation of the groups may not be the optimal way to do it because the current language groups may not fully represent the group dynamics. Future research should include more homogenous groups or form one-language or one-culture groups. Third, the number of humorous scenarios included in the study is limited. Future humor researchers might use more humorous scenarios to better examine ELLs' comprehension of different humor types.

Despite the limitations mentioned above, this study offers a number of pedagogical and theoretical implications for English language teaching education. First, this study provided evidence that humor definitely has a place in language education and is, to a great extent, appreciated by ELLs. Indeed, when used properly, the 'haha' of humor can lead to the 'aha' of learning (Garner, 2006). Therefore, humor should be part of English teachers' teaching repertoire. However, humor used in English classrooms should be comprehensible and pertinent to the content. English teachers should, thus, use the right type of humor considering the proficiency levels of the students. As Schmitz (2002) suggested, universal humor can be teachers' first go-to type of classroom humor as this type is suitable for all levels. As the proficiency level increases, linguistic and cultural humor might be implemented as well. When 
teaching multicultural and multilingual groups, English teachers should be extra cautious because although humor is a universal phenomenon, there might be cultural differences in the appreciation of humor. For example, when compared to the Asian group, Turkish and European students responded more positively to the employment of humor. Additionally, given the largely supportive perceptions of ELLs in this study, English teachers may want to develop humor competence (Wulf, 2010) and insert humor into course syllabus in a systematic way to help learners improve their linguistic, cultural and communicative competence (Szirmai, 2012). For instance, in-service teachers and teacher trainees can be armed with the necessary skills and knowledge to effectively employ humor in English language classrooms through including a humor session in teacher training at colleges. In addition, English teachers might attend workshops or read humor research published in several humor journals (e.g., International Journal of Humor Research) that investigate humor from various perspectives and offer effective ways to incorporate humor in class.

\section{Conclusion}

This study investigated how a multicultural group of ELLs comprehended several types of humor and perceived the employment of classroom humor used in English classes. The quantitative and qualitative data revealed that universal humor should be the first go-to source of humor to use with ELLs. Along with ELLs' largely positive attitudes towards the proper employment of humor in the classroom, several important roles and potent benefits were linked to humor such improving teacher-student rapport, lowering affective barriers to language learning, increasing learners' attentiveness, attention span and confidence. Taken together, if used with care, humor can offer several benefits to language teachers and students

\section{References}

Askildson, L. (2005). Effects of humor in the language classroom: Humor as a pedagogical tool in theory and practice. Arizona Working Papers in SLAT, 12, 4561.

Attardo, S., Wagner, M. M., \& Urios-Aparisi, E. (2013). Prosody and Humor. Amsterdam: John Benjamins Publishing. https:/ / doi.org/10.1075/ bct.55

Banas, J. A., Dunbar, N., Rodriguez, D., \& Liu, S. J. (2011). A review of humor in educational settings: Four decades of research. Communication Education, 60(1), 115-144. https:/ / doi.org/10.1080/03634523.2010.496867

Bell, N. (2005). Exploring L2 language play as an aid to SLL: A case study of humor in NS-NNS interaction. Applied Linguistics, 26(2), 192-218. https:/ / doi.org/10.1093/applin/amh043

Bell, N. (2009). Learning about and through humor in the second language classroom. Language Teaching Research, 13(3), 241-258. https:/ / doi.org/10.1177/1362168809104697

Bell, Nancy (2017). Humor and second language development. In Salvatore Attardo (Ed.), The Routledge handbook of language and humor (pp. 444-455). New York, New York: Routledge. 
Berk, R. (1996). Student ratings of 10 strategies for using humor in college teaching. Journal of Excellence in College Teaching, 7(3), 71-92.

Berk, R. (2000). Does humor in course tests reduce anxiety and improve performance? College Teaching, 48(4), 151-159. https:/ / doi.org/10.1080/87567550009595834

Berk, R., \& Nanda, J. P. (1998). Effects of jocular instructional methods on attitudes, anxiety, and achievement in statistics courses. Humor, 11(4), 383-409. https:/ / doi.org/10.1515/humr.1998.11.4.383

Chen, G. H., \& Martin, R. A. (2007) A comparison of humor styles, coping humor, and mental health between Chinese and Canadian university students. Humor: International Journal of Humor Research, 20(3), 215-234. https:// doi.org/10.1515/HUMOR.2007.011

Creswell, J. W., \& Plano-Clark, V. L. (2011). Designing and conducting mixed methods research (2nd ed.). Thousand Oaks, CA: SAGE Publishing.

Deneire, M. (1995). Humor and foreign language teaching. Humor: International Journal of Humor Research, 8(3), 285-298. https:/ / doi.org/10.1515/humr.1995.8.3.285

Forman, R. (2011). Humorous language play in a Thai EFL classroom. Applied Linguistics, 32(5), 541-565. https:/ / doi.org/10.1093/applin/amr022

Garner, R. L. (2006). Humor in pedagogy: How ha-ha can lead aha! College Teaching, 54(1), 177-180. https://doi.org/10.3200/CTCH.54.1.177-180

Gervais, M., \& Wilson, D. S. (2005). The evolution and functions of laughter and humor: A synthetic approach. Quarterly Review of Biology, 80(4), 395-430. https:/ / doi.org/10.1086/498281

Gonulal, T. (2018). Investigating the potential of humour in EFL classrooms: An attitudinal study. European Journal of Humour Research, 6(1), 141-161. https://doi.org/10.7592/EJHR2018.6.1.gonulal

Gonulal, T. (forthcoming). Missing data management practices in L2 research: The good, the bad and the ugly. Erzincan University Journal of Education Faculty.

Jiang, F., Yue, X. D., \& Lu, S. (2011). Different attitudes toward humor between Chinese and American students: evidence from the Implicit Association

Test. Psychological reports, 109(1), 99-107. https:/ / doi.org/10.2466/09.17.21.PR0.109.4.99-107

Liao, C. C. (2001) Taiwanese perceptions of humor: a sociolinguistic perspective. Taipei, Taiwan: Crane.

Loewen, S. \& Gonulal, T. (2015). Exploratory factor analysis and principal components analysis. In Plonsky, L. (Ed), Advancing quantitative methods in second language research. New York: Routledge.

Illés, S. \& Akcan, S. (2017). Bringing real-life language use into EFL classrooms. ELT Journal, 71(1), 3-12. https:// doi.org/10.1093/elt/ccw049

Martin, R. A. (2007). The psychology of humor: An integrative approach. Cambridge: Cambridge University Press.

McKnight, P. E., McKnight, K. M., Sidani, S., \& Figueredo, A. J. (2007). Missing data: A gentle introduction. New York, NY: Guilford Press

Neuliep, J. W. (1991). An examination of the content of high school teacher's humor in 
the classroom and the development of an inductively derived taxonomy of classroom humor. Communication Education, 40(4), 343-355.

https:// doi.org/10.1080/03634529109378859

Petraki, E., \& Nguyen, H. H. P. (2016). Do Asian EFL teachers use humor in the classroom? A case study of Vietnamese EFL university teachers. System, 61, 98109. https:/ / doi.org/10.1016/j.system.2016.08.002

Plonsky, L., \& Derrick, D. J. (2016). A meta-analysis of reliability coefficients in second language research. The Modern Language Journal, 100(2), 538-553. https:// doi.org/10.1111/modl.12335

Plonsky, L. \& Gonulal, T. (2015). Methodological synthesis in quantitative L2 research: A review of reviews and a case study of exploratory factor analysis. Language Learning, 65(S1), 9-36. https:/ / doi.org/10.1111/lang.12111

Pomerantz, A., \& Bell, N. D. (2011). Humor as safe house in the foreign language classroom. The Modern Language Journal, 95(s1), 148-161. https:// doi.org/10.1111/j.1540-4781.2011.01274.x

Schmitz, J. R. (2002). Humor as a pedagogical tool in foreign language and translation courses. Humor-International Journal of Humor Research, 15(1), 89-113. https:/ / doi.org/10.1515/humr.2002.007

Szirmai, M. (2012). Raising multicultural awareness by teaching humor in foreign language classes. In G. Alao, M.D. Plard, E. Suzuki and S. Y. Roger (Eds.), Didactique plurilingue et pluriculturelle: l'acteur en contexte mondialisé (pp. 193202). Paris: Editions Des Archives Contemporaines.

Tabachnick B., \& Fidell, L. (2013). Using multivariate statistics. Boston: Pearson Education Inc.

Torok, E. S., McMorris, F. R., \& Lin, W. (2004). Is humor an appreciated teaching tool? Perceptions of professors' teaching styles and use of humor. College Teaching, 52(1), 14-20. https:/ / doi.org/10.3200/CTCH.52.1.14-20

Wagner, M., \& Urios-Aparisi, E. (2011). The use of humor in the foreign language classroom: Funny and effective? Humor-International Journal of Humor Research, 24(4), 399-434. https:/ / doi.org/10.1515/humr.2011.024

Wanzer, M. B. (2002). Use of humor in the classroom: The good, the bad, and the notso-funny things that teachers say and do. In J. Chesebro and J. McCroskey (Eds.), Communication for teachers (pp. 116-125). Boston: Allyn \& Bacon.

Wanzer, M. B., Frymier, A. B., \& Irwin, J. (2010). An explanation of the relationship between instructor humor and student learning: Instructional humor processing theory. Communication Education, 59(1), 1-18. https:/ / doi.org/10.1080/03634520903367238

Wulf, D. (2010). A humor competence curriculum. TESOL Quarterly, 44(1), 155-169. https:// doi.org/10.5054/tq.2010.215250

Yue, X., Jiang, F., Lu, S., \& Hiranandani, N. (2016). To be or not to be humorous? Cross cultural perspectives on humor. Frontiers in Psychology, 7, 1495-1498. https:// doi.org/10.3389/fpsyg.2016.01495

Zhang, Q. (2005). Immediacy, humor, power distance, and classroom communication apprehension in Chinese college classrooms. Communication Quarterly, 53(1), 
109-124. https:/ / doi.org/10.1080/01463370500056150

\section{Authors' Biodata / Yazar Bilgileri}

Talip GONULAL is an assistant professor applied linguistics at Erzincan Binali Yildirim University, Turkey. His primary research interests center around quantitative research methods, statistical literacy, classroom humor, and technologyenhanced language teaching and learning.

Talip GONULAL Erzincan Binali Yıldırım Üniversitesi İngiliz Dili Eğitimi bölümünde doktor öğretim üyesi olarak çalışmaktadır. Ana araştırma alanları arasında nicel araştırma metotları, istatistiksel okur-yazarlık, sınıf içi espri kullanımı ve teknoloji odaklı yabancı dil öğretimi ve öğrenimi yer almaktadır. 